MINI RISET

\title{
PENGARUH PAJAK PERTAMBAHAN NILAI (PPN) DAN PAJAK \\ PENJUALAN ATAS BARANG MEWAH (PPNBM) TERHADAP DAYA \\ BELI KONSUMEN PADA KENDARAAN BERMOTOR RODA DUA \\ (Suatu Penelitian Pada Dealer Yamaha Armada Pagora Jaya \\ Bandung Tulungagung)
}

\author{
May Vicky Amalia (1960302100034) \\ Vickyamalia43@gmail.com \\ Ajeng Yuliandri Putri Adi (196030210035) \\ Ajengypa1025@gmail.com \\ Sinta Era Ardian Lupita Sari (1960302100041) \\ Sintaera11@gmail.com
}

\begin{abstract}
This artcle aims to determine the effectiveness of policies or tax laws that exist in preventing and combating the transfer pricing practices of multinational companies on a case by Armada Yamaha Pagora Jaya and tax privileges granted to importers to increase acceptance of import value-added tax (VAT) taxable goods. In conducting this study, the authors use the method of normative juridical approach. Toyota suspected of 〈playing〉 with a related party transaction prices and adds to costs through royalty payments are not fair. Thousands of car production Toyota Motor Manufacturing Indonesia exported overseas with reasonable prices. This mode is thought to be the transfer pricing strategy. Therefore diadakanlah Advance Pricing Agreement (APA), which is useful for reducing the practice of transfer pricing by multinational companies. Facilities that are likely to be enjoyed by employers taxable imports taxable goods is the tax payable is free and exempt from valueadded tax $(V A T)$.
\end{abstract}

Keywords : transfer pricing, value-added tax, import

\begin{abstract}
ABSTRAK
Artikel ini bertujuan untuk mengetahui efektifitas kebijakan atau peraturan perpajakan yang ada dalam mencegah dan menanggulangi praktik transfer pricing pada perusahaan multinasional berdasarkan kasus Armada Yamaha Pagora Jaya serta fasilitas perpajakan yang
\end{abstract}


diberikan kepada importir untuk meningkatkan penerimaan Pajak Pertambahan Nilai (PPN) Impor Barang Kena Pajak. Dalam melakukan penulisan ini penulis menggunakan metode pendekatan Yuridis Normatif. Toyota diduga 'memainkan' harga transaksi dengan pihak terafiliasi dan menambah beban biaya lewat pembayaran royalti secara tidak wajar. Ribuan mobil produksi Toyota Motor Manufacturing Indonesia diekspor ke luar negeri dengan harga yang tidak wajar. Modus ini diduga merupakan strategi transfer pricing. Maka dari itu diadakanlah Advance Pricing Agreement (APA) yang berguna untuk mengurangi terjadinya praktik penyalahgunaan transfer pricing oleh perusahaan multinasional. Fasilitas yang kemungkinan dapat dinikmati oleh pengusaha kena pajak yang mengimpor Barang Kena Pajak adalah pajak terutang yang tidak dipungut dan dibebaskan dari pengenaan Pajak Pertambahan Nilai (PPN).

Kata kunci: transfer pricing, pajak pertambahan nilai, impor 


\section{PENDAHULUAN}

\section{Latar Belakang}

Pajak merupakan sumber penerimaan Negara disamping penerimaan dari sumber migas dan non migans. Dengan posisi yang sedemikian itu pajak merupakan penerimaan strategis yang dikelola dengan baik. Dalam struktur keuangan Negara tugas dan fungsi penerimaan pajak dijalankan oleh Direktorat Jenderal Pajak dibawah Departemen Keuangan Republik Indonesia.

Latar belakang diperlakuannya Pajak Penjualan atas Barang Mewah setiap pemungutan pajak termasuk pemungutan pajak Pertambahan Nilai diharapkan mencerminkan keadialan baik secara horizontal maupun vertikal. Untuk mencapai sasaran agar pemungutan Pajak Pertambahan Nilai mencerminkan keadilan tersebut maka diberlakukan pemungutan Pajak Penjualan atas Barang Mewah.

Pajak adalah gejala masyarakat, artinya pajak hanya ada di dalam masyarakat. Masyarakat adalah kumpulan manusia yang pada suatu waktu berkumpul untuk tujuan tertentu. Negara adalah masyarakat yang mempunyai tujuan tertentu. Kelangsungan hidup negara juga berarti kelangsungan hidup masyarakat dan kepentingan masyarakat. Untuk kelangsungan hidup masing- masing diperlukan biaya. Biaya hidup individu, menjadi beban dari individu yang bersangkutan dan berasal dari penghasilannya sendiri. Biaya hidup negara adalah untuk kelangsungan alat-alat negara, administrasi negara, lembaga negara, dan seterusnya, dan harus dibiayai dari penghasilan negara. Pada mulanya pajak belum merupakan suatu pungutan, tetapi hanya merupakan pemberian sukarela oleh rakyat kepada raja dalam memelihara kepentingan negara, seperti menjaga keamanan negara, menyediakan jalan umum, membayar gaji pegawai dan lain- lain. Bagi penduduk yang tidak melakukan penyetoran maka ia diwajibkan melakukan pekerjaan-pekerjaan untuk kepentingan umum untuk beberapa hari lamanya dalam satu tahun. Penghasilan negara adalah berasal dari rakyatnya melalui pungutan pajak, dan atau dari hasil kekayaan alam yang ada dalam negara itu. Dua sumber itu merupakan sumber terpenting yang memberikan penghasilan kepada negara. Penghasilan itu untuk membiayai kepentingan umum yang akhirnya juga mencakup kepentingan pribadi individu seperti kesehatan masyarakat, pendidikan, kesejahteraan dan sebagainya. Jadi, dimana ada kepentingan masyarakat, disana timbul pungutan pajak sehingga pajak adalah senyawa dengan kepentingan umum.

Pungutan pajak mengurangi penghasilan atau kekayaan individu tetapi sebaliknya merupakan penghasilan masyarakat yang kemudian di kembalikan lagi kepada masyarakat, melaui pengeluaran-pengeluaran rutin dan pengeluaran pembangunan yang akhirnya kembali 
lagi kepada seluruh masyarakat yang bermanfaat bagi rakyat, baik yang membayar maupun tidak. Pajak mempunyai peran yang sangat penting bagi kehidupan bernegara, khususnya didalam pembangunan karena pajak merupakan sumber penghasilan negara untuk membiayai semua pengeluaran, termasuk pengeluaran pembangunan.

Sistem pemungutan pajak pertambahan nilai (PPN) di indonesia adalah Self Assessment System,yang berarti wajib pajak diberikan kepercayaan untuk memperhitungkan, menyetorkan, dan melaporkan sendiri atas pajak yang terhutang terhadap Negara merupakan cara yang paling mudah yang dilakukan pemerintah untuk memungut pajak, yaitu dengan cara mewajibkan wajib pajak untuk melakukan pungutan dan pemungutan pajaknya oleh pihak lain. Dengan cara ini maka pemerintah tidak perlu mengeluarkan biaya yang besar untuk memungut pajak. Dalam pemungutan pajak subjek dan objek pajak harus jelas. Oleh karena itu harus dikelola dengan baik dan benar sehingga data wajib pajak sesuai. Selain itu, tarif pajak harus ditentukan berdasarkan ketentuan yang berlaku saat itu. Dengan demikian para wajib pajak dapat rutin dan patuh membayar pajak. Subjek pajak adalah orang, badan atau kesatuan lainnya yang telah memenuhi syarat-syarat subjektif, yaitu bertempat tinggal atau berkedudukan di Indonesia. Subjek pajak baru menjadi wajib pajak bila telah memenuhi syarat- syarat obyektif. Objek pajak adalah apa yang dikenakan pajak. Mengingat penting dan strategisnya objek pajak karena menyangkut apa yang dikenakan atau tidak dikenakannya pajak atas objek dimaksud, sehingga dalam UU perpajakan kita selalu dengan tegas dinyatakan apa yang menjadi objek setiap jenis pajak. (Ratnawati \& Rachmad Gesah Mukti Prabowo, 2019)

\section{Tujuan Penelitian}

Dari rumusan masalah tersebut, tujuan yang ingin dicapai ialah menganalisis Pengaruh Pajak Pertambahan Nilai (PPN) terhadap daya beli konsumen kendaraan bermotor roda dua. Menganalisis Pengaruh Pajak Penjualan atas Barang Mewah (PPnBM) terhadap daya beli konsumen kendaraan bermotor roda dua. Menganalisis Pengaruh Pajak Pertambahan Nilai (PPN) dan Pajak Penjualan atas Barang Mewah (PPnBM) terhadap daya beli konsumen kendaraan bermotor roda dua. 


\section{LANDASAN TEORI}

\section{A. Pengertian Pajak Pertambahan Nilai}

Pajak pertambahan nilai merupakan pengganti dari pajak penjualan. Hal ini disebabkan karena pajak penjualan tidak lagi memadai untuk menampung kegiatan masyarakat dan belum mencapai sasaran kebutuhan pembangunan, antara lain untuk meningkatkan penerimaan Negara, mendorong ekspor dan pemerataan pembebanan pajak.

Menurut Supramono dalam (Putri Intan Permata Sari et al., 2019) pajak pertambahan nilai merupakan pajak yang dikenakan atas konsumsi di dalam negeri, baik konsumsi BKP maupun JKP. Berdasarkan penjelasan UU Nomor 42 tahun 2009 tentang perubahan ketiga atas UU Nomor 8 tahun 1983 tentang pajak pertambahan nilai dan jasa dan pajak penjualan atas barang mewah, pada bagian umum, pajak pertambahan niali adalah pajak konsumsi barang dan jasa di daerah pabean yang dikenakan secara bertingkat disetiap jalur produksi dan ditribusi.

Menurut Waluyo dalam (Putri Intan Permata Sari et al., 2019)menyatakan bahwa pajak pertambahan nilai merupakan pajak yang dikenakan atas konsumsi di dalam daerah pabean, baik konsumsi barang maupun konsumsi jasa.

Mardiasmo dalam (Putri Intan Permata Sari et al., 2019) menatakan bahwa apabila dilihat dari sejarahnya, pajak pertambahan nilai merupakan pengganti dari pajak penjualan. Alasan pengertian ini karena pajak penjualan dirasa sudah tidak lagi memadai untuk menampung kegiatan masyarakat dan belum mencapai sasaran kebutuhan pembangunan, antara lain untuk meningkatkan penerimaan negara, mendorong ekspor dan pemerataan pembebanan pajak.

Mardiasmo dalam (Putri Intan Permata Sari et al., 2019) pajak penjualan mempunyai kelemahan, yaitu :

1. Adanya pajak ganda

2. Macam-macam tarif, sehingga menimbulkan kesulitan

3. Tidak mendorong ekspor

4. Belum dapat mengatasi penyelundupan

Sedangkan pajak pertambahan nilai (PPN) mempunyai kelebihan, yaitu :

1. Menghilangkan pajak ganda

2. Menggunakan tarif tunggal sehingga mudah pelaksanaannya

3. Netral dalam persaingan dalam negeri, perdagangan nasional. Netral pola konsumsi dalam mendorong ekspor. 


\section{B. Dasar Hukum Pajak Pertambahan Nilai (PPN)}

Berlakunya UU No. 42 Tahun 2009 tentang perubahan ketiga atas UU No. 8 Tahun 1983 kemudian diubah menjadi UU No. 11 Tahun 1994, dan yang terakhir diubah lagi dengan UU No. 18 Tahun 2000 tentang pajak pertambahan nilai (PPN) barang dan jasa dan pajak penjualan atas barang mewah. aturan pelaksanaan terakhir diatur pada UU No. 42 Tahun 2009.

Dengan UU No. 8 Tahun 1983 dipungut pajak pertambahan nilai dan penjualan atas barang mewah. Perbedaan utama pajak pertambahan nilai dari peredaran dan pajak penjualan 1951 adalah tidak adanya unsur pajak berganda.

Undang-undang yang mengatur pengenaan pajak pertambahan nilai (PPN) barang dan jasa serta pajak penjualan atas barang mewah adalah undang- undang No. 8 Tahun 1983 kedua pajak ini merupakan sebagai pajak yang dipungut atas konsumsi dalam negeri. khususnya terhadap penjualan atau penyerahan barang mewah selain dikenakan pajak pertambahan nilai juga dikenalkan pajak penjualan atas barang mewah.

Dalam undang-undang ditemukan bahwa UU PPN diberlakukan 1 juli tahun 1984, dengan praturan pemerintah penganti UU (PERPEU) No. 1 Tahun 1984. Mulainya berlaku UU PPN ditangguhkan sampai tanggal 1 juli 1986, dan ditetapkan peraturan pemerintah (Brotodiharjo, 1991)

\section{Mekanisme Pemungutan Pajak Pertambahan Nilai}

Mekanisme pemungutan PPN sesuai dengan PMK Nomor 85/PMK.03/2012 tanggal 06 Juni 2012 yang berlaku efektif mulai 1 Juli 2012 adalah:

1. Mekanisme pemungutan PPN yang pertama dan wajib adalah rekanan wajib membuat faktur pajak dan surat setoran pajak (SSP) atas setiap penyerahan BKP dan/atau JKP kepada BUMN.

2. Mekanisme pemungutan PPN yang kedua adalah faktur pajak sebagaimana dimaksud pada angka 1 dibuat sesuai dengan ketentuan di bidang perpajakan.

3. Ketiga adalah SSP sebagaimana dimaksud pada angka 1 diisi dengan membubuhkan NPWP serta identitas rekanan, tetapi penandatanganan SSP dilakukan oleh BUMN sebagai penyetor atas nama rekanan.

4. Keempat adalah dalam hal penyerahan BKP selain terutang PPN juga terutang PPnBM maka rekanan harus mencantumkan juga jumlah PPnBM yang terutang pada faktur pajak. 
5. Kelima adalah faktur pajak dibuat dalam rangkap 3 dengan peruntukkan sebagai berikut : lembar kesatu untuk BUMN, lembar kedua untuk rekanan, dan lembar ketiga untuk BUMN yang dilampirkan pada SPT Masa PPN bagi pemungut PPN.

6. Keenam adalah SSP sebagaimana dimaksud pada angka 1 dibuat dalam rangkap 5 dengan peruntukkan sebagai berikut : lembar kesatu untuk rekanan, lembar kedua untuk KPPN melalui Bank Persepsi atau Kantor Pos, lembar ketiga untuk rekanan yang dilampirkan pada SPT Masa PPN, lembar keempat untuk Bank Persepsi atau Kantor Pos, dan lembar kelima untuk BUMN yang dilampirkan pada SPT Masa PPN bagi Pemungut PPN.

7. Mekanisme Pemungutan PPN yang terakhir adalah faktur Pajak dan SSP merupakan bukti pemungutan dan penyetoran PPN atau PPN dan PPnBM. (Ratnawati \& Prabowo, n.d.)

\section{Barang Kena Pajak (PKB)}

Menurut UU No. 42 tahun 2009 pasal 1(3) baran kena pajak adalah barang berwujud yang menurut sifat atau hukumnya dapat berupa barang bergerak atau barang tidak bergerak dan barang tidak berwujud yang dikenakan pajak berdasarkan UU.

Menurut Mardiasmo (2008:274) BKP adalah barang berwujud yang menurut sufat atau hukumnya dapat berupa barang bergerak atau barang tidak bergerak, dan barang tidak berwujud yang dikenakan pajak berdasarkan UU PPN.

Menurut Waluyo (2011:12) BKP adalah barang berwujud yang menurut sifat atau hukumnya dapat berupa barang bergerak atau barang tidak bergerak dan barang tidak berwujud yang dikenai pajak berdasarkan UU PPN dan PPnBM. (Pajak et al., 2020)

\section{E. Jasa Kena Pajak (JKP)}

Menurut UU No. 18 tahun 2000 dan No. 42 tahun 2009 pasal 1(6) PKP adalah setiap kegiatan pelayanan berdasarkan suatu perikatan atau perbuatan hokum yang menyebabkan suatu barang atau fasilitas atau memberi kemudahan atau hak tersedia untuk dipakai, termasuk jasa yang dilakukan untuk menghasilkan barang karena pesanan dan bahan dan petunjuk pemesan.

Suhartono dan Ilyas dalam (Putri Intan Permata Sari et al., 2019) menyatakan bahwa dalam UU PPN No. 42 tahun 2009 menjelaskan bahwa pengusaha yang melakukan penyerahan BKP atau penyerahan JKP yamg tergolong pengusaha tidak diwajibkan untuk dikukuhkan sebagai PKP, kecuali pengusaha kecil tersebut memilih untuk dikukuhkan sebagai PKP. 


\section{F. Pengecualian Barang Kena Pajak (BKP)}

Pada dasarnya semua barang adalah barang kena pajak, kecuali UU menetapkan sebaliknya. Jenis barang yang tidak dikenakan PPN ditetapkan dengan peraturan pemerintah berdasarkan atas kelompk-kelompok barang sebagai berikut:

a. Barang hasil pertambangan, penggalian, dan pengeboran, yang diambil langsung dari sumbernya seperti: minyak tanah, gas bumi, batu bara dll.

b. Barang-barang kebutuhan pokok yang sangat dibutuhkan oleh banyak rakyat seperti: beras, gabah, jagung, sagu, buah-buahan, sayur-sayuran dll.

c. Makanan dan minuman yang disajikan di hotel, restoran, rumah makan, warung dan sejenisnya meliputi makanan dan minuman baik yang dikonsumsi ditempat maupun tidak.

d. Uang, emas batangan, dan surat-surat berharga (saham, obligasi). (Citra Kunia putri dan trisna insan Noor, 2013)

\section{G. Pengecualian Jasa Kena Pajak (JKP)}

Pada dasarnya semua jasa dikenakan pajak, kecuali yamg ditentukan lain oleh UU PPN pada UU No. 42 tahun 2009, menurut Mardiasmo dalam (Putri Intan Permata Sari et al., 2019) kelompk jasa yang tidak dikenakan pajak pertambahan nilai adalah jasa pelayanan kesehatan medis, jasa pelayanan social, jasa pengiriman surat dengan perangko, jasa keuangan, jasa asuransi dll.(Direktorat/Jendral pajak, 2009) 


\section{MODE PENELITIAN}

\section{Desain Penelitian}

Jenis penelitian yang digunakan dalam penelitian ini adalah penelitian ekperimental yang merupakan bentuk penelitian percobaan yang berusaha untuk mengisolasi dan melakukan kontrol setiap kondisi-kondisi yang relevan dengan situasi yang ditelityi kemudian melakukan pengamatan terhadap efek kondisi yang sedang terjadi.

\section{Subjek Penelitian}

Penelitian dilakukan pada Dealer Yamaha Pagora Jaya Bandung Tulungagung. Sedangkan waktu yang digunakan selama melakukan penelitian dimulai dari bulan April sampai dengan Mei 2021.

\section{Prosedur Penelitian}

Adapun langkah-langkah yang dilakukan dalam penelitian ini adalah sebagai berikut :

a. Observasi Tempat Penelitian

b. Mengajukan Permohonan Penelitian

c. Pengumpulan Data

d. Analisa Data Penelitian

e. Analisa Penerapan

f. Kesimpulan dan Saran

\section{Metode Analisis Data}

Penelitian ini dilakukan dengan menggunakan metode analisis deskriptif kualitatif, yaitu dengan menganalisis, menggambarkan, dan meringkas berbagai kondisi, situasi dari berbagai data yang dikumpulkan berupa hasil wawacara atau pengamatan mengenai masalah yang diteliti yang terjadi di lapangan 


\section{PEMBAHASAN}

\section{Profil Perusahaan}

PT. ARMADA PAGORA JAYA yang kemudian disebut YAMAHA ARMADA PAGORA berdiri pada tanggal 16 September 1996 berada di jl. Bandung-Durenan Desa Suruhan Lor Kecamatan Bandung Kabupaten Tulungagung. Pada tanggal 24 September 1997 membuka cabang YAMAHA ARMADA PAGORA TULUNGAGUNG yang pada awalnya berada di Jl. Supriyadi 28 Tulungagung kemudian sekarang pindah di gedung sendiri di Jl. Patimura no.40 Tertek Tulungagung.YAMAHA ARMADA PAGORA adalah Dealer Resmi Yamaha 3S (SALES, SERVIS, SPARE PART) yang melayani Penjualan (SALES) secara Tunai, Kredit maupun Arisan, melayani SERVIS dan melayani penjualan SPARE PART.

Dengan perkembangan yang sedemikian pesat di penjualan sepeda motor YAMAHA umum maka pada tanggal 17 Nopember 2007 kembali memperluas jaringan After Sales dengan membuka cabang ARMADA PAGORA NGADILUWIH di Jl. Raya Ngadiluwih 117 Ngadiluwih, Kediri yang berstatus 2S (SERVIS, SPARE PART). Pada tanggal 16 juli 2009 membuka kembali cabang ARMADA PAGORA PAGU di jl. JOYOBOYO 127 Sitimerto, Pagu, Kediri dengan Status Bengkel MITRA YAMAHA dan kemudian meningkat status sebagai BENGKEL RESMI YAMAHA yang berstatus 2S dan berpindah di gedung sendiri di J1. A. Yani no. 98 Sambirobyong. Kayen Kidul.

YAMAHA ARMADA PAGORA berkomitmen untuk menjadi RAJANYA DEALER YAMAHA dalam pelayanan terhadap PELANGGAN dengan mengutamakan kualitas palayanan dengan pelayanan berstandart Bintang Lima, kami ingin layanan, kenyamanan dan keamanan akan dirasakan berbeda dan yang terbaik oleh Pelanggan ARMADA PAGORA dengan slogan "ARMADA PAGORA JAYA BERKELAS DALAM KUALITAS, TERDEPAN DALAM PELALAYANAN" YAMAHA SEMAKIN DI DEPAN

\section{Deskripsi Responden}

\begin{tabular}{|l|l|c|c|}
\hline No. & \multicolumn{1}{|c|}{ Karakteristik Responden } & Frekuensi & Presentase (\%) \\
\hline 1. & Jumlah sampel & $\mathbf{1 8 7}$ & $\mathbf{1 0 0 \%}$ \\
\hline 2. & Jenis Kelamin & & \\
& a. Pria & 715 & $61 \%$ \\
& b. Wanita & $\mathbf{1 8 7}$ & $39 \%$ \\
& Jumlah & & $\mathbf{1 0 0 \%}$ \\
\hline 3. & Usia Responden & 88 & $48 \%$ \\
& a. 20-29 Tahun & 42 & $22 \%$ \\
\hline
\end{tabular}




\begin{tabular}{|l|l|c|c|}
\hline & c. 40-49 Tahun & 42 & $22 \%$ \\
& d. > 50 Tahun & 15 & $8 \%$ \\
& Jumlah & $\mathbf{1 8 7}$ & $\mathbf{1 0 0 \%}$ \\
\hline 4. & Pendidikan Terakhir & & \\
& a. SMU / Sederajat & 67 & $36 \%$ \\
& b. Diploma & 22 & $12 \%$ \\
& c. S 1 & 82 & $44 \%$ \\
& d. S 2 / S 3 & 16 & $8 \%$ \\
& Jumlah & $\mathbf{1 8 7}$ & $\mathbf{1 0 0 \%}$ \\
\hline 5. & Pendapatan rata-rata perbulan & 17 & $9 \%$ \\
& a. Rp 1.000.000 s/d Rp 2.000.000 & 96 & $51 \%$ \\
& b. Rp 2.000.000 s/d Rp 5.000.000 & 60 & $32 \%$ \\
& c. Rp 5.000.000 s/d Rp 10.000.000 & 14 & $8 \%$ \\
& d. > Rp 10.000.000 & $\mathbf{1 8 7}$ & $\mathbf{1 0 0 \%}$ \\
\hline
\end{tabular}

Dengan demikian berdasarkan hasil deskripsi karakterisrik responden dalam penelitian ini, dapat dismpulkan bahwa yang lebih banyak menjadi konsumen kendaraan bermotor roda empat dan roda dua pada PT. Hasjrat Abadi Manado selama tahun 2014, dan yang mendominasi penelitian ini adalah responden pria yang berusia sekitar 20-29 tahun, dengan tingkat pendidikan Strata 1 (S1) dan memiliki pendapatan berkisar Rp2.000.000Rp5.000.000 per bulan.

\section{Hasil Penelitian}

\section{Analisis Regresi Linier Berganda}

Kendaraan Bermotor Roda Dua

\begin{tabular}{|l|r|r|}
\hline \multirow{2}{*}{ Model } & \multicolumn{2}{|c|}{$\begin{array}{c}\text { Unstandardized } \\
\text { Coefficients }\end{array}$} \\
\cline { 2 - 3 } & \multicolumn{1}{|c|}{ B } & \multicolumn{1}{c|}{ Std. Error } \\
\hline 1 (Constant) & 14.826 & 2.773 \\
\hline Pajak Pertambahan Nilai & 088 & 119 \\
\hline Pajak Penjualan atas Barang Mewah & 244 & 121 \\
\hline
\end{tabular}

Persamaan Regresi $\mathrm{Y}=14,826+0,088 \mathrm{X} 1+0,244 \mathrm{X} 2$ menggambarkan bahwa variabel bebas (independen) Pajak Pertambahan Nilai (X1) dan Pajak Penjualan atas Barang Mewah (X2) dalam model regresi tersebut dapat dinyatakan satu variabel independen berubah sebesar 1 (satu) dan lainnya konstan, maka perubahan variabel terikat (dependen) Daya Beli Konsumen Kendaran Bermotor Roda Dua (Y) adalah sebesar nilai (b) dari nilai variabel independen tersebut. 
Konstanta (a) sebesar 14,826 memberikan pengertian bahwa jika Pajak Pertambahan Nilai (X1) dan Pajak Penjualan atas Barang Mewah (X2) secara serempak atau bersama-sama tidak mengalami perubahan atau sama dengan nol (0) maka besarnya Daya Beli Konsumen (Y) sebesar 14,826 satuan.

Jika nilai b1 yang merupakan koefisien dari Pajak Pertambahan Nilai (X1) sebesar 0,088 yang artinya mempunyai pengaruh positif terhadap variabel dependen (Y) mempunyai arti bahwa jika variabel Pengenaan Pajak Pertambahan Nilai (X1) bertambah 1 satuan, maka Daya Beli Konsumen (Y) juga akan mengalami kenaikan sebesar 0,088 satuan dengan asumsi variabel lain tetap atau konstan.

Jika nilai b2 yang merupakan koefisien regresi dari Pajak Penjualan atas Barang Mewah (X2) sebesar 0,244 yang artinya mempunyai pengaruh positif terhadap variabel dependen (Y) mempunyai arti bahwa jika variabel Pengenaan Pajak Penjualan atas Barang Mewah (X2) bertambah 1 satuan, maka Daya Beli Konsumen (Y) akan mengalami kenaikan sebesar 0,244 satuan dengan asumsi variabel lain tetap atau konstan.

Uji F Kendaraan Bermotor Roda Dua

\begin{tabular}{|c|c|}
\hline F & Sig. \\
\hline 3.420 & $.037^{\mathrm{b}}$ \\
\hline
\end{tabular}

Dari hasil Uji F menunjukan bahwa nilai signifikan adalah 0,037 berarti lebih kecil $(<)$ dari 0,05 maka H0 ditolak atau Ha diterima. Kesimpulannya yaitu, Pajak Pertambahan Nilai (X1) dan Pajak Penjualan atas Barang Mewah (X2) secara bersama-sama berpengaruh signifikan terhadap Daya Beli Konsumen Kendaran Bermotor Roda Dua (Y).

Uji t Kendaraan Bermotor Roda Dua

\begin{tabular}{|c|c|c|}
\hline Model & T & Sig \\
\hline (Contant) & 5.347 & 000 \\
\hline Pajak Pertambahan Nilai & 740 & 461 \\
\hline Pajak Penjualan atas Barang Mewah & 2.008 & 048 \\
\hline
\end{tabular}

Dari hasil Uji t dapat diketahui bahwa Probabilitas (signifikan) X1 sebesar 0,461 lebih besar (>) dari 0,05 maka H0 diterima atau Ha ditolak. Kesimpulannya yaitu Pajak Pertambahan Nilai (X1) tidak berpengaruh terhadap Daya Beli Konsumen Kendaraan Bermotor Roda Dua (Y).

Sedangkan untuk Probabilitas (signifikan) X2 sebesar 0,048 lebih kecil $(<$ )dari 0,05 maka Ha diterima atau H0 ditolak. Kesimpulannya yaitu Pajak Penjualan atas Barang Mewah 
(X2) berpengaruh signifikan terhadap Daya Beli Konsumen Kendaraan Bermotor Roda Dua (Y).

\section{Pembahasan}

Pengaruh Pajak Pertambahan Nilai (PPN) Terhadap Daya Beli Konsumen Kendaraan Roda Dua Armada Yamaha Pagora Jaya

Pajak Pertambahan Nilai adalah pajak atas konsumsi barang dan jasa di Daerah Pabean yang dikenakan secara bertingkat disetiap jalur produksi dan distribusi. Pajak Pertambahan Nilai sangat dipengaruhi oleh perkembangan transaksi bisnis serta pola konsumsi masyarakat yang merupakan objek dari Pajak Pertambahan Nilai. Tarif Pajak Pertambahan Nilai adalah $10 \%$.

Pengenaan Pajak Pertambahan Nilai terhadap barang kena pajak memang sudah sangat dikenal oleh wajib pajak, dalam hal ini yaitu konsumen kendaraan bermotor roda dua

pada Armada Yamaha Pagora Jaya. Sehingga pengenaan dari pajak pertambahan nilai itu sendiri tidak mempengaruhi konsumen dalam membeli suatu kendaraan.

Berdasarkan penelitian yang telah dilakukan pada kedua objek yaitu mengenai pengenaan Pajak Pertambahan Nilai, menunjukan hasil yang tidak berpengaruh terhadap Daya Beli Konsumen Kendaraan Bermotor Roda Dua. Hal ini dikarenakan, jaman sekarang kendaraan bermotor roda dua memang sudah sangat dibutuhkan oleh masyarakat sebagai alat transportasi dalam menjalankan aktivitas sehari-hari, sehingga pengenaan pajak pertambahan nilai yang tarifnya relatif kecil tidak mempengaruhi daya beli dari konsumen

\section{Pengaruh Pajak Penjualan atas Barang Mewah (PPnBM) Terhadap Daya Beli Konsumen Kendaraan Roda Dua Armada Pagora Jaya}

Pajak Penjualan atas Barang Mewah (PPnBM) merupakan bagian dari Pajak Pertambahan Nilai yang dikenakan pada Barang Kena Pajak (BKP) yang tergolong mewah yang dilakukan oleh pengusaha yang menghasilkan, mengimpor, atau mengekspor barang kena pajak yang tergolong mePagorawah tersebut didalam daerah pabean dalam lingkungan perusahaan atau pekerjaannya. Pajak penjualan atas barang mewah dapat mempengaruhi kemampuan membeli konsumen terhadap nilai jual suatu barang, dalam hal ini kendaraan bermotor roda dua pada Armada Pagora Jaya.

Berdasarkan hasil penelitian yang dilakukan pada konsumen kendaraan bermotor roda dua, terdapat pengaruh positif antara PPnBM terhadap daya beli konsumen. Hasil penelitian keduanya menunjukan hasil yang sama, yaitu pengenaan pajak penjualan atas barang mewah berpengaruh terhadap daya beli konsumen kendaraan bermotor pada Armada Pagora Jaya. Artinya semakin tingginya nilai jual suatu kendaraan yang dikenakan pajak 
penjualan atas barang mewah yang tarifnya lebih tinggi dari pajak pertambahan nilai, atau semakin mewah kendaraan tersebut secara signifikan akan mempengaruhi daya beli konsumen kendaraan bermotor. Gengsi dan daya beli yang sangat menentukan pembelian kendaraan bermotor. Walaupun memang belum semua masyarakat yang mengerti benar tentang PPnBM namun tidak menurunkan niat untuk membeli, dikarenakan kebutuhan gengsi sebagai penegasan dari status sosial.

\section{Pengaruh Pajak Pertambahan Nilai (PPN) dan Pajak Penjualan atas Barang Mewah (PPnBM) Terhadap Daya Beli Konsumen Kendaraan Bermotor Roda Dua Armada} Pagora Jaya.

Berdasarkan penelitian yang dilakukan pada konsumen kendaraan bermotor roda dua pada Armada Pador Jaya, menunjukan hasil penelitian yang sama, yaitu bahwa Pajak Pertambahan Nilai dan Pajak Penjualan atas Barang Mewah secara bersama-sama berpengaruh signifikan terhadap Daya Beli Konsumen Kendaraan Bermotor Roda Dua pada Armada Padora Jaya 


\section{KESIMPULAN}

1. Pajak Pertambahan Nilai (PPN) tidak berpengaruh terhadap daya beli konsumen kendaraan bermotor. Pada konsumen kendaraan bermotor roda dua secara parsial, Pajak Pertambahan Nilai (PPN) tidak berpengaruh terhadap daya beli konsumen kendaraan bermotor.

2. Pajak Penjualan atas Barang Mewah (PPnBM) berpengaruh signifikan terhadap daya beli konsumen kendaraan bermotor. 


\section{DAFTAR PUSTAKA}

Brotodiharjo. (1991). Perhitungan PPn. Wandha Mar(8).

Citra Kunia putri dan trisna insan Noor, 2011. (2013). Pajak Pertambahan Nilai. Analisis Pendapatan Dan Tingkat Kesejahteraan Rumah Tangga Petani, 53(9), 1689-1699.

Direktorat/Jendral pajak. (2009). Undang-Undang Pajak Dan Pajak Penjualan Atas Barang Mewah 2009. 1-477.

Pajak, P., Nilai, P., Dan, P. P. N., Atas, P., Mewah, B., \& Terhadap, P. (2020). MINI RISET( Suatu Penelitian Pada Dealer Yamaha Armada Pagora Jaya Bandung Tulungagung ) Dosen Pengampu: R. Gesah Mukti P., SE . Ak, MM Oleh : Progam Studi Manajemen.

Putri Intan Permata Sari, Jannah, F., \& Putri, Y. C. A. (2019). ANALISIS PAJAK PERTAMBAHAN NILAI PADA PERUSAHAAN ASIA GRAHA SUKSES MANDIRI TULUNGAGUNG Oleh.

Ratnawati, E., \& Prabowo, R. G. M. (n.d.). MEKANISME PPN DAN PPnBM.

Ratnawati, E., \& Rachmad Gesah Mukti Prabowo. (2019). MEKANISME PEMUNGUTAN PPN dan PPnBM. 5. 